\title{
PEMANFAATAN LIMBAH TANDAN KOSONG KELAPA SAWIT (TKKS) UNTUK PRODUKSI ETANOL
}

\section{UTILIZATION OF PALM EMPTY FRUIT BUNCHES (EFB) WASTE FOR ETHANOL PRODUCTION}

\author{
Eldha Sampepana ${ }^{1}$, Paluphy Eka Yustini ${ }^{2}$, Titik Nurwidawati ${ }^{3}$ \\ Balai Riset dan Standarisasi Industri Samarinda \\ JIn. Harmonika No. 3 Telp. (0541) 746216, 732274 Faks. (0541) 745431 \\ 1esp_smd@yahoo.com \\ 2 paluphylitha@yahoo.co.id \\ 3 t2k_widayati@yahoo.com
}

Naskah diterima 2 Oktober 2012, disetujui 26 Nopember 2012

\begin{abstract}
ABSTRAK
Limbah tandan kosong kelapa sawit (TKKS) mengandung $\pm 45 \%$ selulosa yang dapat dihidrolisis menjadi gula sederhana menggunakan asam klorida $(\mathrm{HCl})$ dan difermentasi menjadi etanol dan $\mathrm{CO}_{2}$. Tujuan penelitian ini adalah untuk mengetahui konsentrasi $\mathrm{HCl}$ dan waktu optimum hidrolisis pembuatan etanol dari TKKS. Variasi konsentrasi $\mathrm{HCl}$ yang digunakan adalah $2 \mathrm{~N}$ dan $3 \mathrm{~N}$, sedangkan variasi waktu yang digunakan 2 jam dan 3 jam. Hasil hidrolisis kemudian difermentasi menggunakan Saccharomyces cerevisae. Dari hasil penelitian dapat disimpulkan bahwa proses hidrolisis TKKS optimum terjadi pada konsentrasi $\mathrm{HCl} 3 \mathrm{~N}$ selama 2 jam dengan kandungan gula reduksi yaitu16.34\%. Kadar etanol optimum 0,30\% diperoleh dari proses fermentasi selama 3 hari, sedangkan jumlah karbondioksida $\left(\mathrm{CO}_{2}\right)$ optimum dihasilkan pada hari ke-3.
\end{abstract}

Kata kunci : Tandan kosong kelapa sawit, etanol, karbon dioksida $\left(\mathrm{CO}_{2}\right)$

\begin{abstract}
Palm oil empty fruit bunches (EFB) waste contains $\pm 45 \%$ cellulose which can be hydrolyzed into simple sugars using hydrochloric acid $(\mathrm{HCl})$ and fermented into ethanol. The objective of this study was to determine the optimum $\mathrm{HCl}$ concentration and hydrolysis time for ethanol production. $\mathrm{HCl}$ concentration level used was $2 \mathrm{~N}$ and $3 \mathrm{~N}$, and the variation of hydrolysis time period was 2 hourse and 3 hourse. The hydrolysis product was then fermented using Saccharomyces cerevisae. The results showed that the optimum condition of EFB hydrolysis was obtained from concentration $3 \mathrm{~N}$ $\mathrm{HCl}$ during 2 hourse process with 16,34\% of reducing sugar. The optimum ethanol content was $0.30 \%$ which was abtainst after 3 day process. Mean while the optimum of carbon dioxide $\left(\mathrm{CO}_{2}\right)$ was reached on the three day.
\end{abstract}

Keywords : Palm oil empty fruit bunches, ethanol, carbon dioxide $\left(\mathrm{CO}_{2}\right)$ 


\section{PENDAHULUAN}

Tandan kosong kelapa sawit (TKKS) merupakan limbah padat industri minyak kelapa sawit dengan potensi cukup besar yaitu 2,5 juta ton per tahun. Sampai saat ini TKKS hanya dibuang di tempat atau dibakar sehingga menimbulkan pencemaran lingkungan (Roliadi, et. al.I, 2007). TKKS mengandung $\pm 45 \%$ selulosa, $\pm 30 \%$ hemiselulosa, dan $\pm 30 \%$ lignin (Ronny, 2008). Selulosa dapat dihidrolisis menjadi gula sederhana dengan asam atau enzim yang selanjutnya dapat difermentasi menjadi etanol.

Etanol merupakan salah satu bahan bakar alternatif yang saat ini banyak digunakan sebagai alternatif sumber energi dari fosil (Prihandana, et. all., 2007). Dengan kadar selulosa sekitar $45 \%$. TKKS berpotensi untuk dimanfaatkan sebagai bahan baku pembuatan etanol, dengan teknologi bio-konversi yang relatif sederhana. TKKS dapat ditingkatkan nilai tambahnya dan sekaligus merupakan solusi untuk masalah lingkungan dan energi.

Pada hidrolisis TKKS menjadi gula sederhana dengan menggunakan asam kuat. Asam kuat yang umum digunakan adalah asam sulfat $\left(\mathrm{H}_{2} \mathrm{SO}_{4}\right)$ dengan konsentrasi 1-3\% (Prawita, 2010). Pada penelitian ini proses hidrolisis dilakukan menggunakan asam klorida $(\mathrm{HCl})$ dengan variasi waktu, dilanjutkan dengan fermentasi menggunakan Saccharomyces cerevisiae. Tujuan penelitian ini adalah untuk mengetahui konsentrasi $\mathrm{HCl}$ dan waktu optimum hidrolisis pembuatan etanol dari TKKS

\section{METODE PENELITIAN}

\section{Bahan dan Peralatan}

Bahan yang digunakan adalah serbuk kering TKKS dengan ukuran 60 mesh, Saccharomyces cerevisiae, potato desxtrose agar (PDA), media YEPD (Yeast Extract Peptone Dextrose), padat atau cair yang terdiri dari pepton, yeast ekstrak, agar, aquades, bahan nutrisi media: $\left(\mathrm{NH}_{4}\right)_{2} \mathrm{HPO}_{4}, \mathrm{MgSO}_{4} .7 \mathrm{H}_{2} \mathrm{O}, \mathrm{HCl} 2 \mathrm{~N}$ dan $\mathrm{HCl} 3 \mathrm{~N}, 0,3472 \mathrm{~N} \quad \mathrm{~K}_{2} \mathrm{Cr}_{2} \mathrm{O} 7, \mathrm{H}_{2} \mathrm{SO}_{4}, \mathrm{KI}$, $\mathrm{Na}_{2} \mathrm{~S}_{2} \mathrm{O}_{7}, \mathrm{CH}_{3} \mathrm{COOH}, \mathrm{Ca}(\mathrm{OH})_{2}$, kanji, larutan Luff, $\mathrm{HCl} \quad 0,1 \mathrm{~N}$, indikator fenolftalein, kertas $\mathrm{pH}$. Sedangkan alat yang digunakan adalah vortex mixer, sentrifuges, shaker, spektrofotometer, autoklaf, oven, refluks, penanggas, desikator, shaker inkubator, neraca analitik, corong pemisah, pompa vacum, ayakan 60 mesh, vortex, $\mathrm{pH}$-meter, erlenmeyer, erlenmayer tutup ulir, botol laboratorium, gelas ukur, tabung reaksi, pipet, gelas piala, cawan petri, jarum inkubasi dan seperangkat alat fermentor.

\section{Penyiapan Kultur}

Media yeast extract peptone dextrose (YEPD) dibuat dengan cara melarutkan $10 \mathrm{gr}$ yeast ekstrak, $20 \mathrm{gr}$ pepton, 20 gr glukosa dan $18 \mathrm{gr}$ agar ke dalam $1 \mathrm{~L}$ akuades lalu disterilisasi, dan dituang ke dalam cawan petri yang sudah disterilkan. Media yang sudah dingin siap untuk ditanam inokulum. (Ronny, 2008).

Stok kultur pada $S$. cerevisiae dilakukan dengan cara inokulasi sebanyak 1 ose isolat $S$. cerevisiae ke dalam media YEPD dan diinkubasi pada suhu kamar 1 - 2 hari. Pemeliharaan stok kerja pada isolat Saccharomyces cerevisiae dilakukan dengan cara inokulasi 2 ose isolat per $75 \mathrm{ml}$ media YEPD cair steril ke dalam botol jar dan diinkubasi pada suhu kamar selama 3 hari sambil dikocok dengan kecepatan 120 rpm (Ronny, 2008).

\section{Pembuatan Nutrian Media}

Nutrian untuk media dibuat dengan cara melarutkan $50 \mathrm{ml}$ media nutrien steril terdiri dari $1 \mathrm{~g} / \mathrm{L}\left(\mathrm{NH}_{4}\right.$ )$_{2} \mathrm{HPO}_{4}, 0,05 \mathrm{~g} / \mathrm{L} \mathrm{MgSO}{ }_{4} .7 \mathrm{H}_{2} \mathrm{O}$ dan $2 \mathrm{~g} / \mathrm{L}$ 
yeast ekstrak, dengan $\mathrm{pH}$ media 5 (Ronny, 2008).

\section{Proses Hidrolisis dan Fermentasi}

Hidrolisis TKKS dilakukan dengan menggunakan $\mathrm{HCl} 2 \mathrm{~N}$ dan $3 \mathrm{~N}$ dengan variasi waktu hidrolisis 2 jam dan 3 jam. Serbuk TKKS sebanyak $20 \mathrm{gr}$ dimasukkan kedalam erlenmayer bertutup ulir, kemudian masing-masing ditambahkan $200 \mathrm{ml} \mathrm{HCl}$ lalu dihidrolisis dalam autoklaf dengan suhu $121{ }^{\circ} \mathrm{C}$ pada tekanan $1 \mathrm{~atm}$, setelah dingin, disaring untuk pengujian kadar gula pereduksi.
Fermentasi pada masing-masing larutan yang telah dihidrolisis diawali dengan overliming dengan menambahkan $\mathrm{Ca}(\mathrm{OH})_{2}$ sampai $\mathrm{pH} 12$, dipanaskan pada $60{ }^{\circ} \mathrm{C}$ selama 20 jam, kemudian $\mathrm{pH}$ diturunkan kembali menjadi 5,5 dengan cara menambahkan $\mathrm{HCl} 2 \mathrm{~N}$ atau $\mathrm{HCl} 3 \mathrm{~N}$ (bahan hidrolisis yang digunakan) dan disterilisasi. Proses fermentasi menggunakan Saccharomyces cerevisiae dilakukan dengan waktu inkubasi 5 hari. Setiap 24 jam dilakukan pengambilan contoh untuk uji kadar etanol dan gas $\mathrm{CO}_{2}$. Pengamatan dilakukan sampai hari kelima. Diagram alir proses pembuatan etanol dapat dilihat pada Gambar 1.

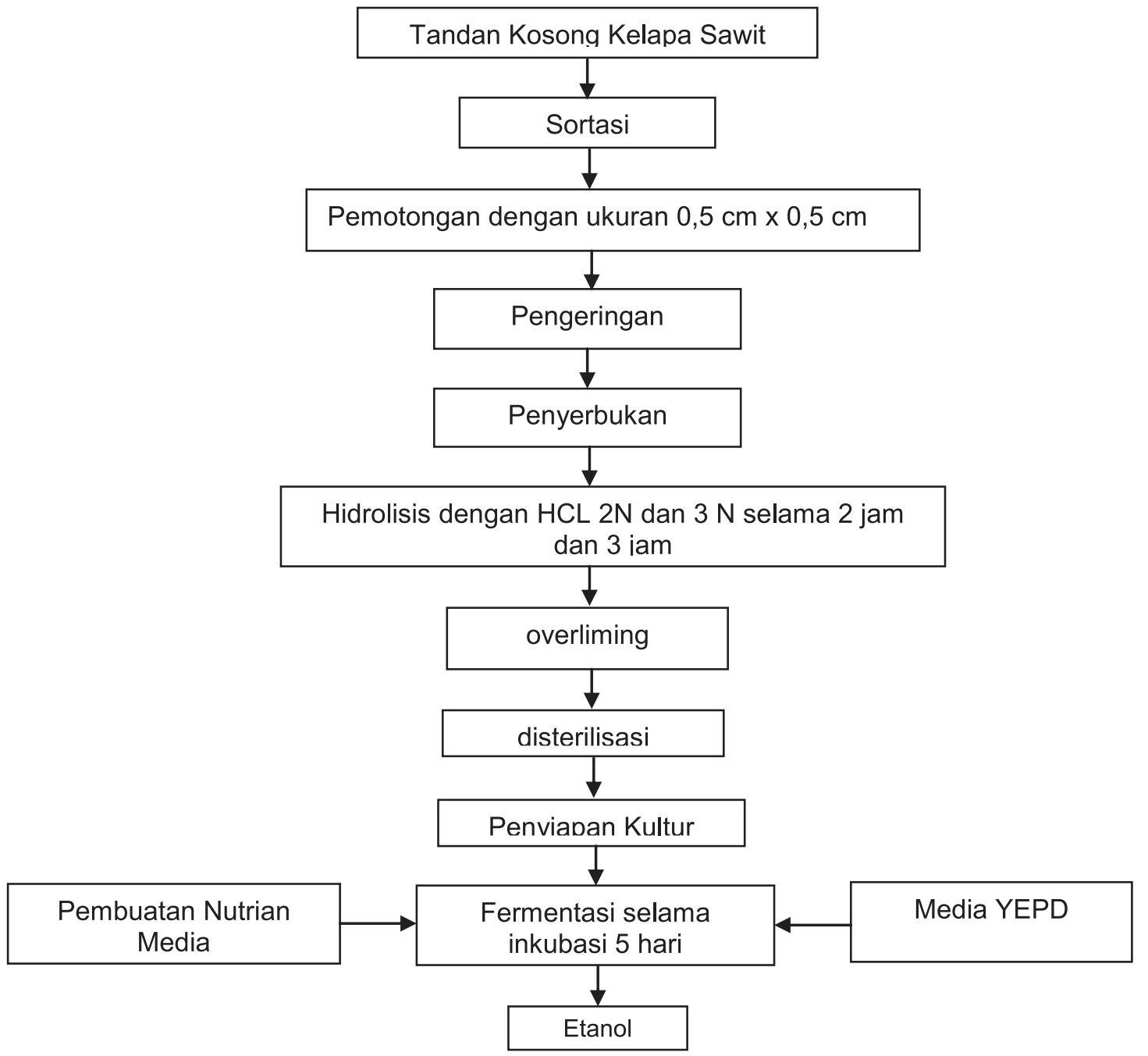

Gambar 2. Diagram Alir Proses Pembuatan Etanol 
Analisis Kadar Gula Reduksi

Analisis gula reduksi berdasarkan metode Luff Schorl Jodometri (Badan Standardisasi Nasional /BSN (1992) dalam Maklupah, 2000).

\section{Analisis Kadar Etanol}

Analisis etanol dilakukan berdasarkan metode Nicloux. (Nicloux, 1931 dalam Loebis, 2008).

\section{Analisis Gas Karbondioksida $\left(\mathrm{CO}_{2}\right)$}

Analisis $\mathrm{CO}_{2}$ berdasarkan metode yang dilakukan Isroi (2008) yaitu karbondioksida $\left(\mathrm{CO}_{2}\right)$ yang dihasilkan dari bagian atas fermentor dialirkan melalui pipa kecil menuju tabung volume ukur yang berisi penuh air. Gas $\mathrm{CO}_{2}$ akan menekan air ke bawah hingga volume air pada tabung tersebut menjadi kosong. Banyaknya volume air yang dikeluarkan sebanding dengan volume gas $\mathrm{CO}_{2}$ yang dihasilkan pada keadaan suhu dan tekanan standar.

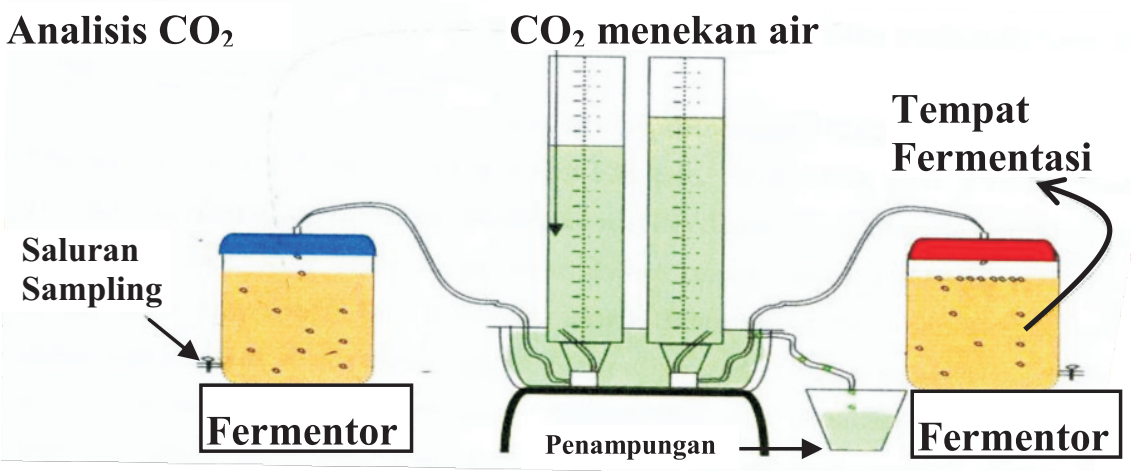

Gambar 2. Rancangan Analisis Kadar $\mathrm{CO}_{2}$ pada Proses Pembuatan Etanol (Loebis, 2008)

\section{HASIL DAN PEMBAHASAN}

\section{Gula Reduksi}

Hasil analisis kadar gula reduksi tkks dapat dilihat pada tabel 1. Kadar gula reduksi tertinggi yaitu $16,34 \%$ diperoleh dari tkks yang dihidrolisis dengan $\mathrm{HCl} 3 \mathrm{~N}$ selama 2 jam, sedangkan kadar gula reduksi terendah $6,20 \%$ diperoleh dari tkks yang dihidrolisis dengan $\mathrm{HCl} 2 \mathrm{~N}$ selama 2 jam. Seiring dengan peningkatan konsentrasi dan waktu terlihat adanya peningkatan konversi selulosa menjadi gula reduksi yang semakin tinggi. Dari Tabel 1 menunjukkan bahwa titik optimum hidrolisis adalah $\mathrm{HCl} 3 \mathrm{~N}$ pada waktu hidrolisis selama 2 jam. Ketika waktu dinaikkan lagi justru terjadi penurunan gula reduksi, ini kemungkinan dapat terjadi karena waktu pemanasan yang lebih lama dapat mendegradasi selulosa menjadi furfural. Menurut Xiang (2003) pada umumnya proses hidrolisis bahan selulosa dengan menggunakan asam kuat pada suhu tinggi akan terjadi degradasi gula dan terbentuk furfural sehingga menghasilkan glukosa sebesar $50 \%$. Hal. Ini dipertegas oleh Rosyida (2011) menyatakan bahwa reaksi yang terjadi dalam proses pembuatan etanol antara lain : 
Reaksi pre-hidrolisa :

$$
\left.\mathrm{C}_{5} \mathrm{H}_{8} \mathrm{O}_{4}\right) \mathrm{n}+\mathrm{n} \mathrm{H}_{2} \mathrm{O} \underset{\text { Asam kuat }}{\longrightarrow} \mathrm{n}\left(\mathrm{C}_{5} \mathrm{H}_{10} \mathrm{O}_{5}\right)
$$

Reaksi Hidrolisa

$$
\left.\mathrm{C}_{6} \mathrm{H}_{10} \mathrm{O}_{5}\right) \mathrm{n}+\mathrm{nH}_{2} \mathrm{O} \longrightarrow \mathrm{nC}_{6} \mathrm{H}_{12} \mathrm{O}_{6}
$$

Asam kuat

\section{Reaksi Fermentasi}

$2 \mathrm{C}_{6} \mathrm{H}_{12} \mathrm{O}_{6}+\mathrm{H}_{2} \mathrm{O} \longrightarrow \mathrm{C}_{2} \mathrm{H}_{5} \mathrm{OH}+\mathrm{CH}_{3} \mathrm{COOH}+2 \mathrm{CO}_{2}+2 \mathrm{C}_{3} \mathrm{H}_{8} \mathrm{O}_{3}$

S. cereviceae

Tabel 1. Kadar Gula Reduksi TKKS

\begin{tabular}{|c|c|c|c|c|c|c|}
\hline \multirow{2}{*}{$\begin{array}{c}\text { Waktu } \\
\text { Hidrolisis }\end{array}$} & \multicolumn{4}{|c|}{ Gula Reduksi (\%) } & \multicolumn{2}{c|}{$\begin{array}{c}\text { Gula Yang Terpakai } \\
\text { (\%) }\end{array}$} \\
\cline { 2 - 7 } & \multicolumn{2}{|c|}{ Setelah dihidrolisis } & Setelah difermentasi & \multicolumn{2}{|c|}{} \\
\cline { 2 - 7 } & $\mathbf{H C I}$ 2N & HCI 3N & HCI 2N & HCI 3N & HCI 2N & HCI 3N \\
\hline 2 jam & 6,20 & 16,34 & 4,80 & 3,84 & 22,58 & 76,50 \\
\hline 3 jam & 12,48 & 12,48 & 3,84 & 3,84 & 69,23 & 69,23 \\
\hline 4 jam & 4,53 & 9,85 & - & - & - & - \\
\hline
\end{tabular}

Keterangan :

- : pada penelitian pendahuluan, pengujian kadar gula reduksi pada perlakuan setelah fermentasi tidak dilakukan pengujian karena melihat nilai kadar gula reduksi setelah hidrolisis asam klorida $(\mathrm{HCl})$ dengan konsentrasi $2 \mathrm{~N}$ dan $3 \mathrm{~N}$ pada waktu 4 jam lebih rendah pada waktu hidrolisis 2 jam sehingga tidak dilanjutkan ke proses pembuatan etanol.

Setelah proses fermentasi terjadi penurunan gula reduksi, hal ini menunjukkan bahwa gula sederhana telah terfermentasi menjadi etanol dan $\mathrm{CO}_{2}$. Pengertian gula yang terpakai yaitu gula yang digunakan $\mathrm{S}$. Ceriviceae dalam merombak gula sederhana menjadi etanol dan $\mathrm{CO}_{2}$. Gula yang terpakai tertinggi mencapai $76.50 \%$ pada konsentrasi $\mathrm{HCl} 3 \mathrm{~N}$ dengan waktu 2 jam (Tabel 1). Nilai tersebut diambil dengan rumus:

$$
\text { Gula yang terpakai }=\frac{\text { Gula reduksi setelah dihidrolisis }- \text { Gula setelah difermentasi }}{\text { Gula reduksi setelah dihidrolisis }} \times 100 \%
$$

Tabel 1. memberikan gambaran setelah proses fermentasi masih ada sisa gula reduksi yang belum terpakai, hal ini menunjukkan bahwa belum semua gula reduksi terurai oleh mikroba
Saccharomyces cerevicae menjadi etanol dan gas $\mathrm{CO}_{2}$. Hal ini disebabkan karena larutan asam yang digunakan pada hidrolisis memotong rantai selulosa menjadi selulosa rantai pendek sehingga terbentuknya HMF (5-Hidroksi 
Metil Furfural) yang digunakan sebagai senyawa inhibitor pertumbuhan pada saat terjadi aktivitas pertumbuhan mikroba, sehingga konversi selulosa menjadi gula tidak banyak terjadi. (Taherzadeh (1999) dan Ulbricht et al. (1984) dalam Shofiyanto, 2008).

Pada suhu dan tekanan tinggi, glukosa dan xylosa akan terdegradasi menjadi furfural dan HMF. Dekomposisi lanjut akan menjadi asam levulinat dan asam formiat (Mussatto dan Roberto (2004); Palmqvist dan Hahn-Hägerdal, 2000).

Menurut Qi et. all., (2008), kadar gula pereduksi sangat dipengaruhi oleh konsentrasi asam, waktu dan suhu pada saat hidrolisis. Pengunaan asam dan konsentrasi yang tepat sebagai agen penghidrolisis sangat diperlukan.

Ketidakstabilan pada saat hidrolisis mengakibatkan bakteri tidak dapat tumbuh dengan baik karena kandungan lignin dalam tandan kosong sawit yang digunakan sebesar $26,09 \%$, sehingga lignin tersebut menghambat dan menurunkan aktivitas kinerja enzim pada proses sakarifikasi (Sun, 2002 dalam Shofiyanto, 2008). Sedangkan menurut Riyani (2009) menyatakan bahwa lignin tidak dapat dihidrolisisis menjadi gula fermentasi karena lignin tersusun oleh komponen bukan gula yakni fonol-propena.

\section{Kadar Etanol}

Gambar 2 menunjukkan bahwa kadar etanol optimum sebesar 0,30\% dihasilkan dari proses hidrolisis dengan $\mathrm{HCl} 2 \mathrm{~N}$ selama 2 jam pada hari ke 3 . Kadar optimum 0,24\% diperoleh dari proses hidrolisis dengan $\mathrm{HCl} 3 \mathrm{~N}$ pada hari ke 2 dan menurun pada hari ke 3 .

Kadar etanol pada hidrolisis $\mathrm{HCl}$ $2 \mathrm{~N}$ dan $\mathrm{HCl} 3 \mathrm{~N}$ selama 3 jam dapat dilihat pada Gambar 3. Kadar etanol yang optimum terjadi pada hari ke-3 yaitu sebesar $0,30 \%$, kemudian mulai turun pada hari ke-4.

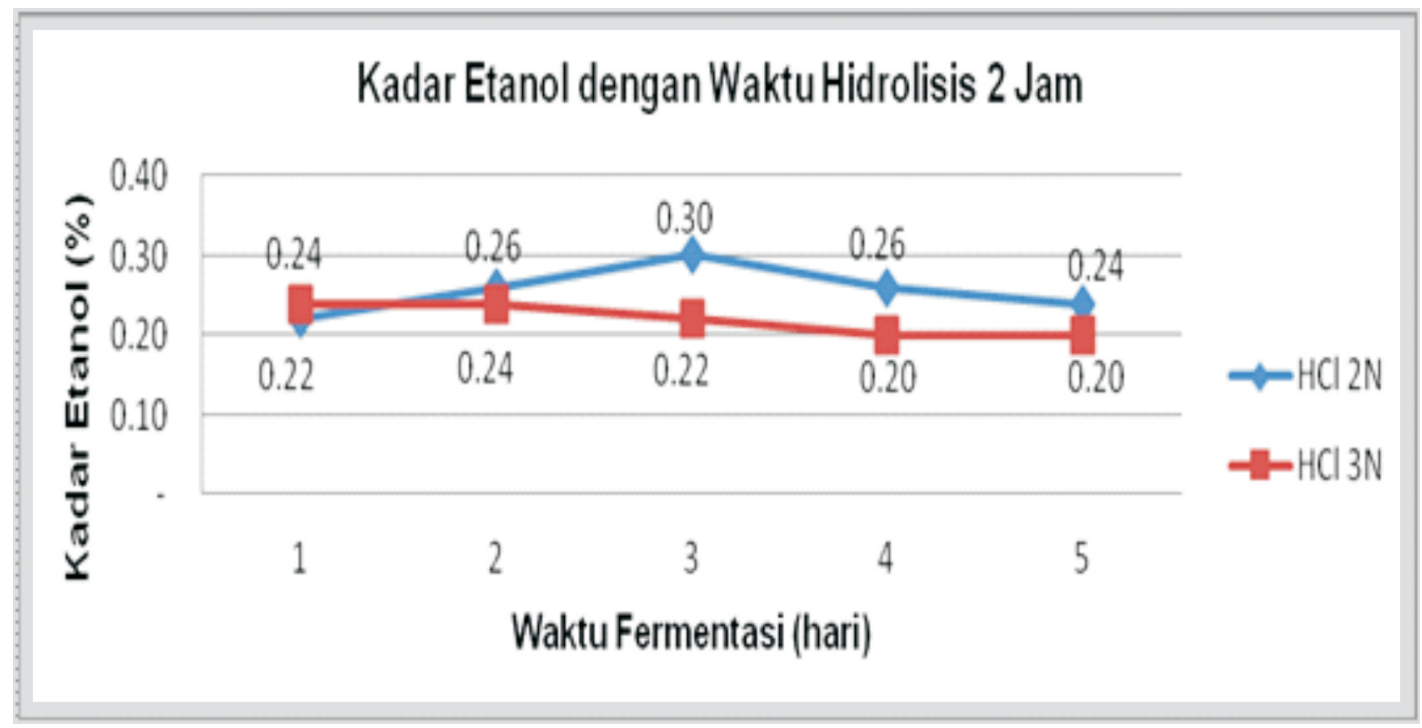

Gambar 2. Kadar Etanol dengan Waktu Hidrolisis 2 jam 


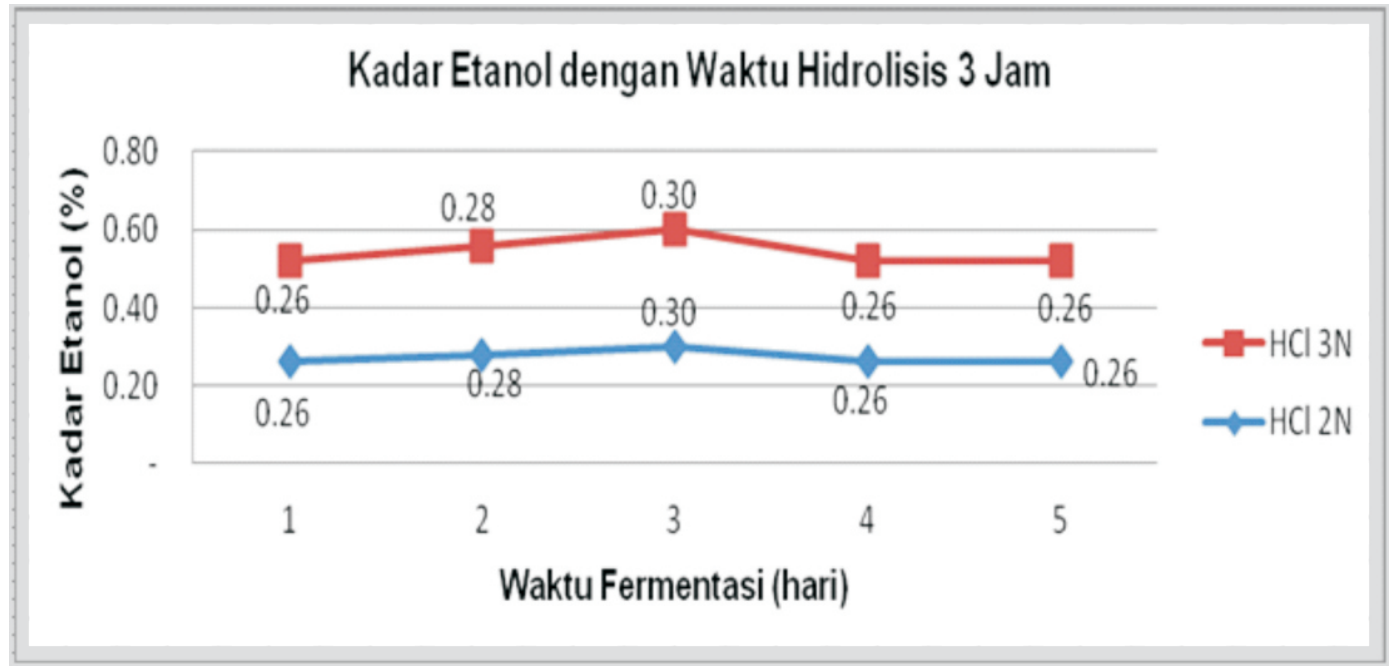

Gambar 3. Kadar Etanol dengan Waktu Hidrolisis 3 Jam.

Dari Gambar 2 dan 3 ditunjukkan bahwa antara hidrolisis 2 dan 3 jam untuk masing-masing variasi konsentrasi, nilai kadar etanol optimum tidak berbeda secara signifikan. Dari kedua gambar tersebut ditunjukkan kadar etanol optimum terjadi pada hari ke 3 dan menurun di hari ke 4 . Kecuali pada $\mathrm{HCl}$ dengan konsentrasi $3 \mathrm{~N}$ selama 2 jam yang mulai menurun di hari ke 3.

Penurunan etanol dapat terjadi karena kemampuan mikroba untuk mengurai gula reduksi mulai menurun dan cenderung stagnan, karena gula reduksi telah terpakai oleh mikroba Saccharomyces cerevicae sebagai substrat. Hal ini dipertegas oleh Maranatha (2008) dalam Shofiyanto (2008) bahwa puncak aktivitas enzim dalam mengurai gula sederhana menjadi etanol terjadi antara hari pertama dan hari kedua.

Menurut Elevri (2006), bahwa produksi etanol akan menurun diakibatkan karena banyaknya penggunaan glukosa pada sel bebas dalam menghasilkan energi pertumbuhan sehingga glukosa yang digunakan dalam memproduksi etanol terbatasi.
Proses fermentasi etanol pada penelitian ini menggunakan mikroba Saccharomyces cerevisae dalam fermentor pada $\mathrm{pH} 5$ dan suhu $30^{\circ} \mathrm{C}$. Saccharomyces cerevicae tumbuh optimum pada pH 4-5 yang menunjukkan kemampuan optimumnya menggunakan glukosa untuk metabolisme sel dan fermentasi etanol pada $\mathrm{pH}$ tersebut. Hal ini dipertegas oleh Ronny (2008) bahwa proses fermentasi bioetanol dengan menggunakan mikroba Saccharomyces cerevicae dalam fermentor berlangsung pada $\mathrm{pH} 5$ dan suhu $30^{\circ} \mathrm{C}$ selama $16-$ 24 jam. Selain itu juga menurut Hidayat (2008) menyatakan suhu yang baik proses fermentasi adalah $25-30^{\circ} \mathrm{C}$, dimana pada suhu tersebut mikroorganisme dapat bekerja secaraoptimal merombak bahan-bahan organik.

Penurunan kadar etanol dapat pula disebabkan oleh berkurangnya kemampuan Saccharomyces cerevicae mengubah gula reduksi akibat adanya penurunan $\mathrm{pH}$. Pada awal proses fermentasi derajat keasaman berkisar pada $\mathrm{pH} 5$ namun pada hari ke 3 mulai terjadi penurunan hingga hari ke 5 dengan kisaran $\mathrm{pH}$ 3-4. Menurunnya konsentrasi etanol pada fermentasi ini disebabkan adanya peristiwa substrat 
inhibitor selama proses fermentasi (Goksungur, et. all., 2001). Hal ini juga dipertegas Sun, (2002) bahwa menurunnya aktifitas mikroorganisme pada proses fermentasi disebabkan karena tingginya lignin yang dapat memperlambat aktivitas mikrooranisme tersebut dalam memecahkan polisakarida menjadi gula sederhana dan etanol pada proses sakarifikasi.

\section{Karbondioksida $\left(\mathrm{CO}_{2}\right)$}

Fermentasi menggunakan mikroba Saccharomyces cerevisae terjadi secara anaerobik. Fermentasi ini ditandai dengan munculnya gelembunggelembung berupa gas $\mathrm{CO}_{2}$, karena terjadinya penguraian glukosa dalam sel sekaligus ditandai dengan turunnya kadar gula reduksi. Hal ini dipertegas oleh Loebis (2008) bahwa fermentasi pada awalnya terjadinya dengan ditandai munculnya gelembung gas $\mathrm{CO}_{2}$, karena adanya penguraian glukosa mulai terjadi dengan turunnya kadar gula reduksi.

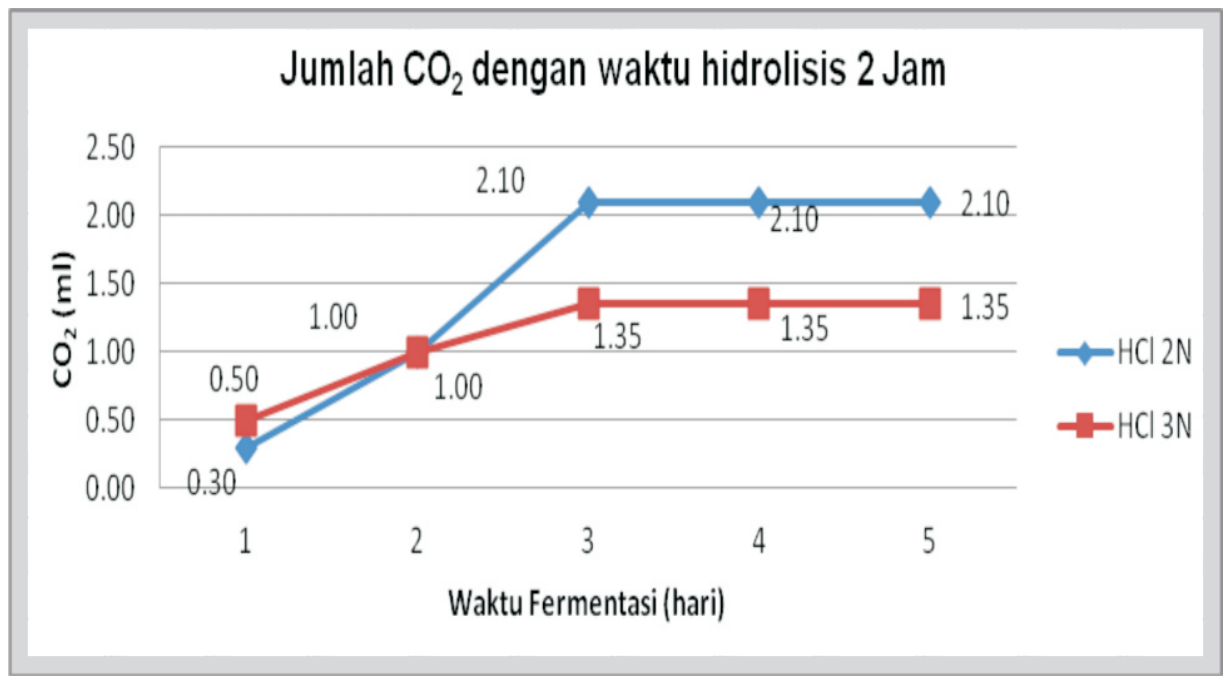

Gambar 4. Jumlah $\mathrm{CO}_{2}$ dengan waktu hidrolisis 2 jam

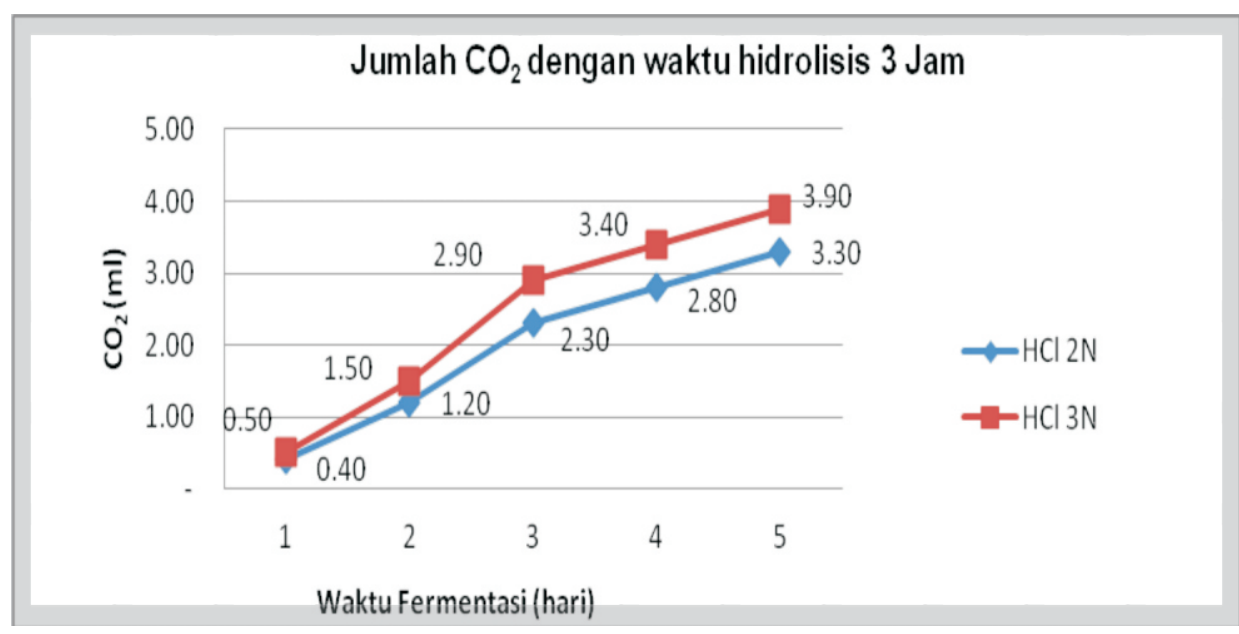

Gambar 5. Jumlah $\mathrm{CO}_{2}$ dengan waktu hidrolisis 3 jam 
Jumlah $\mathrm{CO}_{2}$ dengan waktu hidrolisis 2 dan 3 jam dapat dilihat pada Gambar 4 dan $5 . \mathrm{CO}_{2}$ yang dihasilkan terus meningkat hingga mencapai titik optimum di hari ketiga pada konsentrasi $\mathrm{HCl} 2 \mathrm{~N}$ dan $\mathrm{HCl} 3 \mathrm{~N}$ selama 2 jam yaitu $2,10 \mathrm{ml}$ dan $1,35 \mathrm{ml}$ dan setelah hari ketiga tidak mengalami penambahan volume $\mathrm{CO}_{2}$. Hal ini menunjukkan bahwa pada saat proses fermentasi, gula reduksi diurai oleh mikroba Saccharomyces cerevisae menjadi etanol dan $\mathrm{CO}_{2}$.

Sedangkan untuk hidrolisis $\mathrm{HCl}$ $2 \mathrm{~N}$ dan $\mathrm{HCl} 3 \mathrm{~N}$ selama 3 jam tertinggi pada hari kelima dengan nilai $3,90 \mathrm{ml}$ dan 3,30 ml. Apabila dibandingkan dengan nilai kadar etanol pada waktu fermentasi selama 3 hari, kadar etanol mencapai titik optimum sedangkan kadar $\mathrm{CO}_{2}$ masih meningkat. $\mathrm{Hal}$ ini menunjukkan bahwa pada proses fermentasi etanol, gula reduksi diurai oleh mikroba Saccharomyces cerevisae bukan hanya menjadi etanol dan $\mathrm{CO}_{2}$ melainkan membentuk senyawasenyawa lain seperti furfural, HMF, asetaldehida, asam levulinat dan asam formiat sehingga aktifitas mikroba membentuk senyawa-senyawa tersebut mengakibatkan meningkatnya nilai $\mathrm{CO}_{2}$.

Menurut Shen (2004) bahwa CO2 akan meningkat dalam proses fermentasi etanol disebabkan karena adanya efek inhibisi terhadap pertumbuhan mikroorganisme, volume sel, aktivitas enzim dan kandungan DNA yang menyebabkan terhambatnya penyerapan asam amino yang berantai panjang dalam sel amobil yang menyebabkan meningkatnya tekanan CO2 sehingga mengahasilkan kadar etanol menurun. Jadi kadar optimum $\mathrm{CO}_{2}$ untuk perlakuan hidrolisis $\mathrm{HCl} 2 \mathrm{~N}$ dan $3 \mathrm{~N}$ terjadi pada proses fermentasi selama 3 hari sebesar $2,90 \mathrm{ml}$.

\section{KESIMPULAN}

Dari hasil penelitian dapat disimpulkan bahwa proses hidrolisis tandan kosong kelapa sawit (TKKS) optimum terjadi pada konsentrasi $\mathrm{HCl}$ $3 \mathrm{~N}$ - 2 jam dengan kandungan gula reduksi yaitu16.34\%. Kadar etanol optimum $0,30 \%$ diperoleh dari proses fermentasi selama 3 hari, sedangkan jumlah karbondioksida $\left(\mathrm{CO}_{2}\right)$ optimum dihasilkan pada hari ke-3 sebesar 2,90 $\mathrm{ml}$.

\section{DAFTAR PUSTAKA}

Badan Standardisasi Nasional (BSN). 1992. Standardisasi Nasional Indonesia (SNI) Nomor 01-28921992. Cara Uji Gula. (http://pustan.bpkimi.kemenperin. go.id/, diakses tgl 20 Januari 2009).

Elvri Asga Putra Dan Putra Rosa Surya, 2006. Produksi Etanol Menggunakan Saccharomyces Cerevisiae Yang Diamobilisasi Dengan Agar Batang. Akta Kimindo Vol. 1 No. 2 April 2006: 105-114. Akta Kimia Indonesia. Kimia ITS - HKI Jatim. Surabaya

Goksungur, Y, dan Zorlu, N., 2001, "Production of Ethanol From Beet Molasses by Ca-Alginate Immobilized Yeast Cells in a Packed-Bed Bioreactor", Turk J Biol, 25, hal 265-275.

Shen . S. De Schrijver . N. Moonjai .K. J. Verstrepen . F. Delvaux . F. R. Delvaux, 2004. Effects of $\mathrm{CO} 2$ on the formation of flavour volatiles during fermentation with immobilised brewer's yeast. Appl Microbiol Biotechnol 64: 636 643. Hidayat Nur. 2008. Pembuatan Etanol Dari Sari Kulit Nenas.

http://bioindustri.blogspot.com/20 08/05/pembuatan-etanol-dari- 
sari-kulit-nenas.html.

Diakses

Tanggal 20 Desember 2010.

Isroi, 2008. Fermentor Sederhana Untuk Produksi Etanol. (http://isroi.wordpress.com/

Diakses tanggal 20 Januari 2009).

Loebis Enny Hawani , 2008. Optimalisasi Hidrolisis Serbuk Tandan Kosong Kelapa Sawit Menjadi Glukosa Secara Kimiawi dan Enzimatis Untuk Menghasilkan Etanol Institut Pertanian Bogor. Bogor

Mussatto, S.I. and Roberto, I.C., 2004. Alternatives for Detoxification of Dilute Acid Lignocellulosic Hydrolyzates forUse In Fermentative process : A Review. Bioresource Technology. 93, 110.

Nicloux, M., 1931. Compt. Ren. Soc. Biol., 48,841 (1986); Bull. Soc. Chim.Biol., 13, 857.

Palmqvist, E., Hahn-Hägerdal, B., 2000, ReviewPaper

Fermentation

: LignocellulosicHydrolysates II: Inhibitors andMechanisms of Inhibition,

BioresourceTechnology, 74, 25-33

Prihandana, R., Noerwijati, Adinurani, G. P., Setyaningsih, Setiadi, dan Hendroko, 2007. Bioetanol Ubi Kayu Bahan Bakar Masa Depan. AgroMedia Pustaka: Jakarta.

Prawita, Dewi. 2010. Mengolah Limbah Sawit Menjadi Bioetanol dan Kompos.

(http://blogs.unpad.ac.id, diakses tanggal 14 Sepember 2012).

Qi, D., Bergman, M., Aihara, H., Nibu, Y., Mannervik, M. 2008.

$\begin{aligned} & \text { Drosophila Ebi mediates Snail- } \\ & \text { dependent } \\ & \text { repression throughscriptional }\end{aligned}$
induced
$\begin{aligned} & \text { Heacetylation. EMBC3- } \\ & \text { deastone }\end{aligned}$
898--909. (Export to RIS)

Riyani Eny Ida, 2009," Biomasa Sebagai Bahan baku Bioethanol", Jurnal Litbang Pertanian,28 (3),2009, Bogor

Roliadi, Han dan Widya Fatriasari. $2007 . \quad$ Kemungkinan Pemanfaatan Tandan Kosong Kelapa Sawit Sebagai Bahan Baku Pembuatan Papan Serat Berkerapatan Sedang. www.fordA.Mof.org, diakses tanggal 14 september 2012).

Ronny, Purwadi, 2008. Pabrik Ethanol dari Tandan Kosong Kelapa Sawit (Elaeis guineensis) Dengan Proses Fermentasi. Departemen Teknologi Kimia Institut Teknologi Bandung.

Rosyida Arthani, Anggriani Evi, 2011. Pabrik Bioethanol dari Limbah Tandan Kosong Sawit dengan proses Fermentasi. Jurusan Teknik Kimia Fakultas Teknik Institut Teknologi Sepuluh Nopember. Surabaya

Shofiyanto Edy M., 2008 Hidrolisis Tongkol Jagung Oleh Bakteri Selulolitik untuk Produksi Bioetanol Dalam Kultur Campuran. Fakultas Teknologi Pertanian Institut Pertanian Bogor. Bogor.

Sun, Y. dan Cheng, J. 2002.

Hydrolysis of Lignocellulosic Material for Ethanol Production: Areview. Biores. Technol. 83:111. 
Taherzadeh, M.J. 1999. Ethanol from Lignocellulose: Physiological Effects of Inhibitors and Fermentation Strategies. Ph.D. Tesis. Universitas Chalmers, Goteborg, Swedia.

Ulbricht, R.J., Northup, S.J. \& Thomas, J.A. (1984) A review of 5hydroxymethylfurfural (HMF) in parenteral solutions. Fundam. Appl. Toxicol., 4:843-853
Xiang, Q., Lee Y.Y., Pettersson P.O., Torget R. W.. 2003. Heterogeneous Aspects Of Acid Hydrolysis of Alpha Cellulosa. Departemen of Chemical Engineering. Appl. Biochem Biotechnol. Spring 105-108:505 14. 